\title{
THE USE OF CLINOPTILOLITES AS CARRIER OF METFORMIN HYDROCHLORIDE IN DRUG DELIVERY SYSTEM: IN VITRO DRUG RELEASE STUDY
}

\author{
I MADE WISNU ADHI PUTRA*, I GUSTI AYU WITA KUSUMAWATI
}

Department of Nutrition Science, Faculty of Health, Science, and Technology, University of Dhyana Pura, Badung, Bali, Indonesia. Email: made_wisnu84@yahoo.com

Received: 20 December 2017, Revised and Accepted: 17 July 2018

\begin{abstract}
Objective: As an antidiabetic drug, metformin hydrochloride ( $\mathrm{HCl})$ has been well known to possess low oral bioavailability and short half-life. In this study, we prepared the drug delivery system (DDS) of metformin $\mathrm{HCl}$ and clinoptilolite as its carrier. The in vitro drug release profile was further investigated.
\end{abstract}

Methods: DDS was made by encapsulating metformin $\mathrm{HCl}$ on clinoptilolite using the wet impregnation method at various pH and initial concentration of metformin $\mathrm{HCl}$. Fourier transform infrared spectrometer (FTIR), X-ray diffractometer (XRD), and $\mathrm{N}_{2}$ Sorption Analyzer were used to characterize the as-synthesized DDS. Drug release study was conducted by stirring the DDS in simulated gastric fluid and simulated intestinal fluid over $12 \mathrm{~h}$.

Results: The encapsulation process was achieved optimally at pH 7.0 and initial concentration of metformin $\mathrm{HCl}$ of $300 \mathrm{mg} / \mathrm{l}$ (CLI -300 denoted DDS). The results of FTIR and $\mathrm{N}_{2}$ sorption analyzer confirmed the existence of metformin $\mathrm{HCl}$ on clinoptilolites. Meanwhile, the XRD result showed that the crystallinity of clinoptilolites remained unchanged after the encapsulation process. The cumulative drug release in the simulated gastric fluid was found to be higher than that in the simulated intestinal fluid, which indicated the potent influence of pH on the release properties of the drugs. The drug release kinetics of metformin $\mathrm{HCl}$ from clinoptilolite was best fitted into the Korsmeyer-Peppas model with non-Fickian transport mechanism.

Conclusion: We found that clinoptilolite was suitable for DDS application, particularly as a carrier of metformin HCl.

Keywords: Clinoptilolites, Metformin hydrochloride, Drug delivery system.

(C) 2018 The Authors. Published by Innovare Academic Sciences Pvt Ltd. This is an open access article under the CC BY license (http://creativecommons. org/licenses/by/4. 0/) DOI: http://dx.doi.org/10.22159/ajpcr.2018.v11i11.24366

\section{INTRODUCTION}

Type 2 diabetes mellitus is a chronic disease caused by a combination of decreased insulin secretion and decreased insulin sensitivity [1]. The prevalence of this disease, particularly in Indonesia, has increased over the years [2]. Several complications may happen in patients with Type 2 diabetes mellitus, namely autonomic dysfunction, blindness, kidney failure, foot ulcer, amputation, and Charcot joints [3-5]. Metformin hydrochloride $(\mathrm{HCl})$, a biguanide group, has been widely used to treat patients with Type 2 diabetes mellitus as well as a first-line drug for patients with obesity $[6,7]$. Nevertheless, due to its hydrophilic nature, this drug has low oral bioavailability (50-60\%). It is also administered in high dose $[8,9]$. Thus, improving the drug administration property would lower the dose, as metformin $\mathrm{HCl}$ may contribute to Vitamin B12 and folate deficiency [10], kidney disorder [7], and lactic acidosis [11].

The drug delivery system (DDS) has been used to improve the drug properties and minimize the side effects. Moreover, the use of a carrier in the DDS has played an important role to improve the efficacy and safety of drugs by controlling the rate, time, and drug release sites in the body [12]. Various organic compounds have been used as carriers of metformin $\mathrm{HCl}$, such as $\mathrm{O}$-carboxymethyl chitosan nanoparticles [13], bovine serum albumin nanoparticles [14], hydroxylpropyl methylcellulose and ethyl cellulose [15], casein micelles [16], tamarind seed polysaccharide-alginate [17], and unilamellar niosome [18]. Recently, inorganic material has also been used as a drug carrier due to its unique and beneficial attributes, for example, porous material. Its nanosized pores (1-100 nm) allow drug molecules to be trapped within the pores through the interaction with the pore wall. Therefore, prolonged drug release can be achieved [19].
Due to its abundant availability in nature, clinoptilolites are promising materials as drug carrier of metformin $\mathrm{HCl}$. Clinoptilolites are formed by the combination of silicon, aluminum, and oxygen atoms in threedimensional structures. This material has channels and cages in the nano and subnanometer scales, often called micropores [20]. Moreover, clinoptilolites have been recognized for its safe property [21-23] and antidiabetic activity by forming bound to glucose in the blood [24]. The use of clinoptilolites as drug carrier has been reported by some researchers such as a carrier of ketoprofen [25], salicylate acid in aspirin [26], antibiotics [27], and diclofenac [28]. However, there were no reports on the use of clinoptilolites as a carrier of metformin $\mathrm{HCl}$. Applying the hydrophilic nature and the negative surface charge [29], clinoptilolites are appropriate to be used as a carrier of hydrophilic metformin $\mathrm{HCl}$. In this study, metformin $\mathrm{HCl}$ was encapsulated in clinoptilolites at various $\mathrm{pH}$ and initial concentration of metformin $\mathrm{HCl}$. The in vitro drug release test of the DDS was performed in the simulated gastric fluid ( $\mathrm{pH} \mathrm{1.2)} \mathrm{and} \mathrm{in} \mathrm{the} \mathrm{simulated} \mathrm{intestinal} \mathrm{fluid} \mathrm{(} \mathrm{pH} 7.4$ ).

\section{MATERIALS AND METHODS}

Materials

The reagents used in this study were: Metformin $\mathrm{HCl}$, ammonium chloride $\left(\mathrm{NH}_{4} \mathrm{Cl}\right), \mathrm{HCl}$, potassium chloride, potassium hydrogen phosphate, and sodium hydroxide. All of these reagents were analytical grade and purchased from Merck. Clinoptilolite-rich zeolites were from Padalarang, West Bandung Regency, West Java, Indonesia.

\section{Activation of clinoptilolites}

The clinoptilolite powder (passed 200 mesh sieve) was mixed with deionized water and stirred for $24 \mathrm{~h}$ at room temperature. Subsequently, the mixture was filtered and heated at $105^{\circ} \mathrm{C}$ for $3 \mathrm{~h}$. It was then denoted as $\mathrm{CLI}_{0}$. In a $500 \mathrm{ml}$ of the three-necked flask, a total 
of $5.000 \mathrm{~g}$ of dried clinoptilolites and $250 \mathrm{ml}$ of $1 \mathrm{M} \mathrm{NH}_{4} \mathrm{Cl}$ solution were mixed together. The formed suspension was refluxed at $90^{\circ} \mathrm{C}$ for $8 \mathrm{~h}$. After filtered, the obtained solid was then washed with deionized water and dried in an oven at $105^{\circ} \mathrm{C}$ for $3 \mathrm{~h}$. Furthermore, the sample was calcined at $550^{\circ} \mathrm{C}$ for $3 \mathrm{~h}$. Activated clinoptilolite (denoted as $\mathrm{CLI}_{1}$ ) was then analyzed using Fourier transform infrared spectrometer (FTIR), $\mathrm{X}$-ray diffractometer (XRD), and $\mathrm{N}_{2}$ sorption analyzer.

\section{Effect of $\mathbf{p H}$}

To achieve the optimum $\mathrm{pH}$ value for drug encapsulation, $1.000 \mathrm{~g}$ of $\mathrm{CLI}_{1}$ were mixed with $100 \mathrm{ml}$ of $100 \mathrm{mg} / \mathrm{l}$ metformin $\mathrm{HCl}$ solution. The mixture was stirred for $24 \mathrm{~h}$ at room temperature and various $\mathrm{pH}(3,5,7,9$, and 11). The mixture was then filtered and dried in an oven at $105^{\circ} \mathrm{C}$ for $6 \mathrm{~h}$. The amount of encapsulated metformin $\mathrm{HCl}$ on clinoptilolites was determined by gravimetric analysis.

\section{Effect of initial concentration}

A total of $1.000 \mathrm{~g}$ of $\mathrm{CLI}_{1}$ was mixed together with $100 \mathrm{ml}$ of $50 \mathrm{mg} / \mathrm{l}$ metformin $\mathrm{HCl}$ solution. The mixture was stirred for $24 \mathrm{~h}$ at room temperature. This process was conducted at optimum $\mathrm{pH}$ that was achieved in previous work. The mixture was then filtered and dried in an oven at $105^{\circ} \mathrm{C}$ for $6 \mathrm{~h}$. The amount of metformin $\mathrm{HCl}$ encapsulated on $\mathrm{CLI}_{1}$ was determined by gravimetric analysis. In the same way, this process was conducted with different concentrations of metformin $\mathrm{HCl}$ solution of $75,100,150,300,450,750$, and $900 \mathrm{mg} / \mathrm{l}$. The final DDS with the highest amount of drugs encapsulated was denoted as $\mathrm{CLI}_{2}$. Fourier transform infrared spectrometer (FTIR), X-ray diffractometer (XRD), and $\mathrm{N}_{2}$ sorption analyzer were used to characterize the $\mathrm{CLI}_{2}$.

\section{The in vitro drug release study}

The drug release study was performed using the dialysis method [30]. The procedure was described as follows. A total of $0.1 \mathrm{~g}$ of $\mathrm{CLI}_{2}$ sample was inserted into a dialysis bag (cutoff $=12 \mathrm{kDa}$ ) and immersed in $100 \mathrm{ml}$ of buffer solution at a $\mathrm{pH}$ of 1.2 and 7.4. The sample was stirred at $37 \pm 0.5^{\circ} \mathrm{C}$ for $12 \mathrm{~h}$. Every $1 \mathrm{~h}$, as much as $5 \mathrm{ml}$ of buffer solution was collected and replaced with the same volume of fresh buffer. The absorption of the metformin $\mathrm{HCl}$ in the aliquot of buffer solution was measured using a UV-Vis spectrometer (Genesys 10S, Thermo Scientific) at $232 \mathrm{~nm}$. The amount of drug released from the DDS was expressed as percentage cumulative drug release.

$\%$ Cumulativedrug release $=\frac{\mathrm{X}_{\mathrm{t}}}{\mathrm{X}_{0}} \times 100 \%$

Where $\mathrm{X}_{\mathrm{t}}$ is the amount of metformin $\mathrm{HCl}$ released over a period of time $(\mathrm{mg})$ and $\mathrm{X}_{0}$ is the amount of metformin $\mathrm{HCl}$ encapsulated on $\mathrm{CLI}_{2}(\mathrm{mg})$.

\section{RESULTS AND DISCUSSION}

\section{Effect of pH}

Encapsulation of metformin $\mathrm{HCl}$ on clinoptilolites was strongly affected by the $\mathrm{pH}$ value (Fig. 1). It appears that the highest amount of metformin $\mathrm{HCl}$ encapsulated in clinoptilolites $(6.674 \pm 1.209 \mathrm{mg} / \mathrm{g})$ occurs at pH 7. In acidic solution, the clinoptilolite active sites and drug molecules are protonated so that drug-clinoptilolite interaction is very weak. The existence of $\mathrm{pH}$ sensitive-amine groups in metformin $\mathrm{HCl}$ affects its state in the solution [31]. In addition, there is a competition between metformin $\mathrm{HCl}$ and the solvent (water) to become bonded to clinoptilolite active sites [32].

At $\mathrm{pH} 7.0$, both the amine groups of metformin $\mathrm{HCl}$ and the clinoptilolite active sites become fully deprotonated, causing the drug-clinoptilolite interaction to be strong. Metformin $\mathrm{HCl}$ is a hydrophilic and highly soluble drug in water [33]. This drug was found forming hydrogen bonds with hydrophilic molecules such as acids and phenols [34]. Thus, possible interactions between drug molecules and clinoptilolites are hydrophilic interactions (hydrogen bond, dipole-dipole, or dipole ion). Subsequently, the amount of drug encapsulated on clinoptilolites decreases as the solution $\mathrm{pH}$ increase. Negatively charged sites of clinoptilolites and metformin $\mathrm{HCl}$ in basic solution may be the main cause of this trend.

\section{Effect of initial concentration}

The effect of initial concentration of the solution on the amount of the encapsulated drug is shown in Fig. 2. According to the figure, the amount of encapsulated metformin $\mathrm{HCl}$ increases as the initial solution concentration. The highest amount of the encapsulated drug $(19.332 \pm 2.982 \mathrm{mg} / \mathrm{g})$ was obtained at an initial solution concentration of $300 \mathrm{mg} / \mathrm{l}$. However, when the initial concentration of the solution was increased to $450 \mathrm{mg} / \mathrm{l}$, the amount of encapsulated drug was dropped dramatically to $14.304 \pm 2.441 \mathrm{mg} / \mathrm{g}$. The decrease of the encapsulated drug amount continued to $4.289 \pm 0.723 \mathrm{mg} / \mathrm{g}$ at the initial solution concentration of $900 \mathrm{mg} / \mathrm{l}$. This decrease is due to the active sites of clinoptilolite having been saturated with drug molecules in a high drug solution concentration, thus unable to bind the drug molecules [35].

\section{FTIR study}

The existence of functional groups of the samples was observed using a FTIR spectrometer (FTIR 8201, Shimadzu). Fig. 3 shows the FTIR spectrum of clinoptilolite $\left(\mathrm{CLI}_{0}\right)$, activated clinoptilolite $\left(\mathrm{CLI}_{1}\right)$, and DDS of metformin $\mathrm{HCl} /$ clinoptilolite $\left(\mathrm{CLI}_{2}\right)$. In the FTIR spectra of the natural clinoptilolite $\left(\mathrm{CLI}_{0}\right)$, a number of peaks appear on several wavenumbers. The peak at $470.63 \mathrm{~cm}^{-1}$ shows the bending vibration of $\mathrm{TO}_{4}$ ( $\mathrm{T}=\mathrm{Si}$ and Al) tetrahedral $[36,37]$. The peak at $601.79 \mathrm{~cm}^{-1}$ shows the asymmetric stretching vibration of $\mathrm{TO}_{4}$ (double ring external linkage). Peaks at wavenumbers of 789.96 and $1056.99 \mathrm{~cm}^{-1}$ show the symmetric stretching and asymmetric stretching vibrations of the external tetrahedral linkage, respectively [38,39]. The stretching vibration of $-\mathrm{OH}$

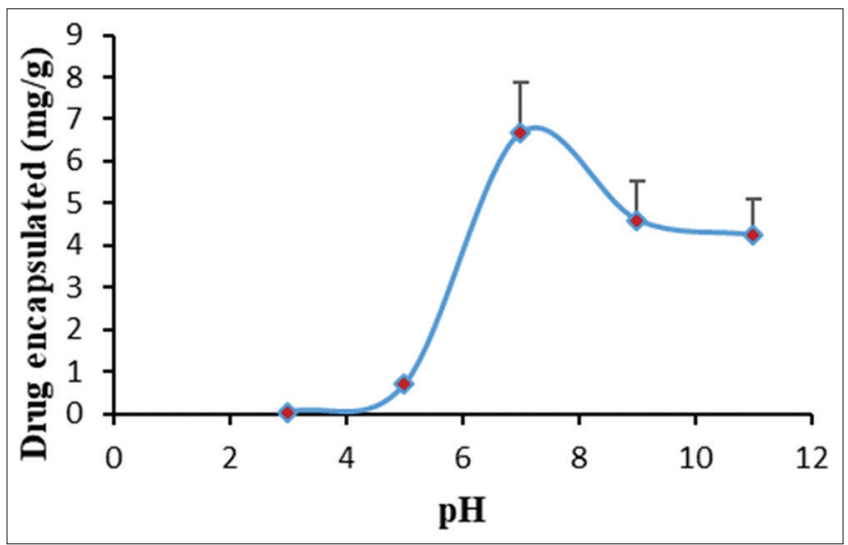

Fig. 1: The amount of drug encapsulated at various pH. Error bars represent the standard deviation $(n=4)$

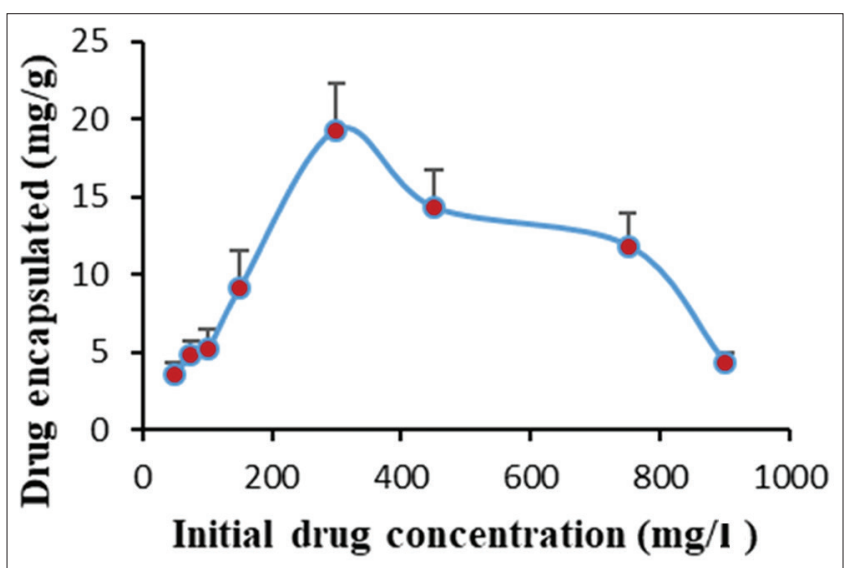

Fig. 2: The amount of drug encapsulated at various initial drug concentration. Error bars represent the standard deviation $(n=4)$ 
from silanol or aluminol groups $(\mathrm{Si}-\mathrm{O}(\mathrm{H})$-Al bridging hydroxyls) appears at $3649.32 \mathrm{~cm}^{-1}$. This vibration is related to Brønsted's acidity. The bending and stretching vibrations of the $-\mathrm{OH}$ group of absorbed water molecules are shown at 1635.64 and $3448.72 \mathrm{~cm}^{-1}$, respectively $[40,41]$.

The FTIR spectra of activated clinoptilolites (CLI) show that the activation of natural clinoptilolite with $\mathrm{NH}_{4} \mathrm{Cl}$ has an effect of peak shifting at some wavenumbers. The peak shifts occurred at 3448.72, 1056.99, and $470.63 \mathrm{~cm}^{-1}$ to $3433.29,1064.71$, and $462.92 \mathrm{~cm}^{-1}$, respectively. These are related to the calcination process of clinoptilolites at $550^{\circ} \mathrm{C}$. According to Farías et al. [42], the heat treatment applied on clinoptilolites may affect the state and placement of aluminum in clinoptilolites.

In the FTIR spectra of the DDS ( $\left.\mathrm{CLI}_{2}\right)$, several shifts are observed at $3649.89,1064.71,601.76$, and $462.92 \mathrm{~cm}^{-1}$ to $3633.89,1072.42,609.51$, and $455.20 \mathrm{~cm}^{-1}$, respectively. These shifts do not seem too wide, indicating the interaction between clinoptilolites and drug molecules is weak. Furthermore, the absorption peaks of metformin $\mathrm{HCl}$ are not observed in the spectra, suggesting that the amount of encapsulated drug molecules is too small. Thus, their appearance is disrupted by the absorption peaks of clinoptilolites [43].

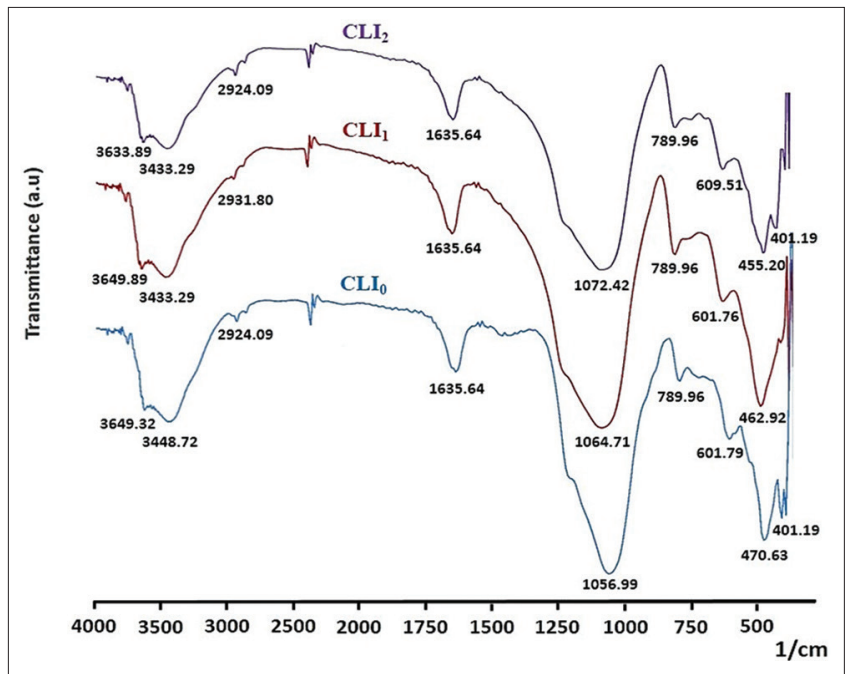

Fig. 3: Fourier transform infrared spectrometer spectra of clinoptilolites ( $\mathrm{CLI}_{0}$ ), activated clinoptilolites (CLI $)$, and metformin $\mathrm{HCl}$ encapsulated clinoptilolite $\left(\mathrm{CLI}_{2}\right)$

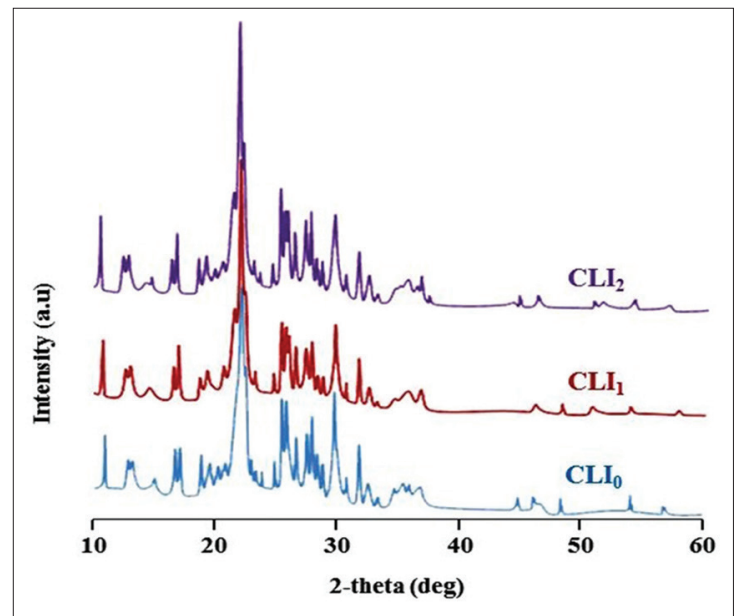

Fig. 4: Diffractogram of clinoptilolites ( $\left.\mathrm{CLI}_{0}\right)$, activated clinoptilolites $\left(\mathrm{CLI}_{1}\right)$, and metformin $\mathrm{HCl}$ encapsulated clinoptilolite ( $\left.\mathrm{CLI}_{2}\right)$
XRD study

The crystallinity of clinoptilolites $\left(\mathrm{CLI}_{0}\right)$, activated clinoptilolites ( $\left.\mathrm{CLI}_{1}\right)$, and metformin $\mathrm{HCl}$ encapsulated clinoptilolite $\left(\mathrm{CLI}_{2}\right)$ were determined using XRD (Philips X'Pert Graphics and Identify). The result is shown in Fig. 4. The clinoptilolites diffraction pattern ( $\mathrm{CLI}_{0}$ ) show strong peaks at $2 \theta=11.151^{\circ}(d=7.28), 17.29^{\circ}(d=5.124), 22.385^{\circ}(d=3.9683), 28.058^{\circ}$ $(\mathrm{d}=3.1777)$, and $29.900(\mathrm{~d}=2.9859)$. Based on the Mineral Powder Diffraction File, JCPDS (25-1349), these peaks are characteristic of clinoptilolite mineral and indicate that clinoptilolites are the main mineral of natural zeolites $[38,43,44]$.

In the activated clinoptilolites ( $\mathrm{CLI}_{1}$ ) pattern, there are no changes observed in the diffraction peaks. Likewise, in the metformin $\mathrm{HCl}$ encapsulated clinoptilolite $\left(\mathrm{CLI}_{2}\right)$ pattern, the diffraction peaks are maintained. This indicates that the crystallinity of clinoptilolites is not impaired by activation with $\mathrm{NH}_{4} \mathrm{Cl}$ nor with the encapsulation of the metformin $\mathrm{HCl}$ molecules [45].

\section{Brunauer-Emmett-Teller (BET) surface area measurement}

The surface area of clinoptilolites (CLI $)$, activated clinoptilolites (CLI), and metformin $\mathrm{HCl}$ encapsulated clinoptilolite $\left(\mathrm{CLI}_{2}\right)$ was measured using $\mathrm{N}_{2}$ Sorption Analyzer (TriStar II 3020, Micromimetics). The calculation was based on BET method. The results of the BET surface area measurement are shown in Table 1. It can be seen that the surface area of clinoptilolites $\left(\mathrm{CLI}_{0}\right)$ is $48.0731 \pm 0.6032 \mathrm{~m}^{2} / \mathrm{g}$. This value increases drastically to $110.2712 \pm 2.4540 \mathrm{~m}^{2} / \mathrm{g}$ after activation with $\mathrm{NH}_{4} \mathrm{Cl}$ and calcination. It is due to the calcination process caused the increase of surface area, total pore volume, and micropore volume of clinoptilolites [46]. At high temperature $\left(500^{\circ} \mathrm{C}\right)$, dehydroxylation was occurred in clinoptilolites which lead to the formation of one Lewis site from two Bröensted sites [42].

Encapsulation of metformin $\mathrm{HCl}$ in $\mathrm{CLI}_{1}$ results in drastic reduction in the surface area. When loaded with $50 \mathrm{mg} / \mathrm{l}$ of metformin $\mathrm{HCl}$, the surface area of activated clinoptilolites ( $\left.\mathrm{CLI}_{2}-50\right)$ decreases to $54.0341 \pm 0.9724 \mathrm{~m}^{2} / \mathrm{g}$. Furthermore, the increase of metformin $\mathrm{HCl}$ concentration to $300 \mathrm{mg} / \mathrm{L}$ makes the surface area of activated clinoptilolites ( $\left.\mathrm{CLI}_{2}-300\right)$, decreases to $34.8993 \pm 0.3870 \mathrm{~m}^{2} / \mathrm{g}$. The decrease of the surface area indicates that the encapsulation process has proceeded well. Some researchers have also confirmed this result. Łukarska et al. [47] showed a very drastic reduction in surface area when they encapsulated fluorescein in zeolite Y. Putra and Mustika [48] also reported the same result, that the encapsulation of solasodine drastically lowered the surface area of clinoptilolites.

\section{Drug release study}

Drug release study was performed in vitro in the simulated gastric fluid ( $\mathrm{pH} \mathrm{1.2)} \mathrm{and} \mathrm{the} \mathrm{simulated} \mathrm{intestinal} \mathrm{fluid} \mathrm{(} \mathrm{pH} \mathrm{7.4)} \mathrm{for} 12 \mathrm{~h}$. Fig. 5 shows the release pattern of metformin $\mathrm{HCl}$ from $\mathrm{CLI}_{2}$. In the lower $\mathrm{pH}$ (1.2), the release of metformin $\mathrm{HCl}$ was observed reaching 83.36\% within $7 \mathrm{~h}$. Furthermore, the release of metformin $\mathrm{HCl}$ took place slowly until it reaches $85.32 \%$ in $12 \mathrm{~h}$. In the higher $\mathrm{pH}$ (7.4), the drug release occurred very fast until the first $2 \mathrm{~h}$. This is due to the weak interaction between drug molecules and the surface of clinoptilolites. In addition, the hydrophilic properties of metformin $\mathrm{HCl}$ also have an effect on this stage [49]. Subsequently, drug release occurred quite slowly $(71.10 \%$ of drug release in $12 \mathrm{~h}$ ). The drug release from clinoptilolites was begun with the diffusion of the

Table 1: BET surface area of the samples $(n=3)$

\begin{tabular}{ll}
\hline Sample codes & BET surface area $\left(\mathbf{m}^{2} / \mathbf{g}\right) \pm \mathbf{S D}$ \\
\hline $\mathrm{CLI}_{0}$ & $48.0731 \pm 0.6032$ \\
$\mathrm{CLI}_{1}$ & $110.2712 \pm 2.4540$ \\
$\mathrm{CLI}_{2}-50$ & $54.0341 \pm 0.9724$ \\
$\mathrm{CLI}_{2}-300$ & $34.8993 \pm 0.3870$ \\
\hline
\end{tabular}

BET: Brunauer-Emmett-teller, SD: Standard deviation, $\mathrm{CLI}_{0}$ : Clinoptilolites, $\mathrm{CLI}_{1}$ : Activated clinoptilolites, $\mathrm{CLI}_{2}-50$ : Activated clinoptilolite-metformin $\mathrm{HCl} 50 \mathrm{mg} / \mathrm{l}, \mathrm{CLI}_{2}-300$ : Activated clinoptilolite-metformin $\mathrm{HCl} 300 \mathrm{mg} / \mathrm{l}$ 
Table 2: Release kinetics data of metformin $\mathrm{HCl}$

\begin{tabular}{llllll}
\hline Release media & Zero-order & First-order & Higuchi & \multicolumn{2}{l}{ Korsmeyer-Peppas } \\
\cline { 2 - 6 } & $\mathbf{R}^{\mathbf{2}}$ & $\mathbf{R}^{\mathbf{2}}$ & $\mathbf{R}^{\mathbf{2}}$ & $\mathbf{R}^{2}$ & $\mathbf{n}$ \\
\hline Buffer pH 1.2 & 0.7723 & 0.4416 & 0.9363 & 0.9776 & 0.69 \\
Buffer pH 7.4 & 0.5038 & 0.3028 & 0.7677 & 0.9119 & 0.64 \\
\hline
\end{tabular}

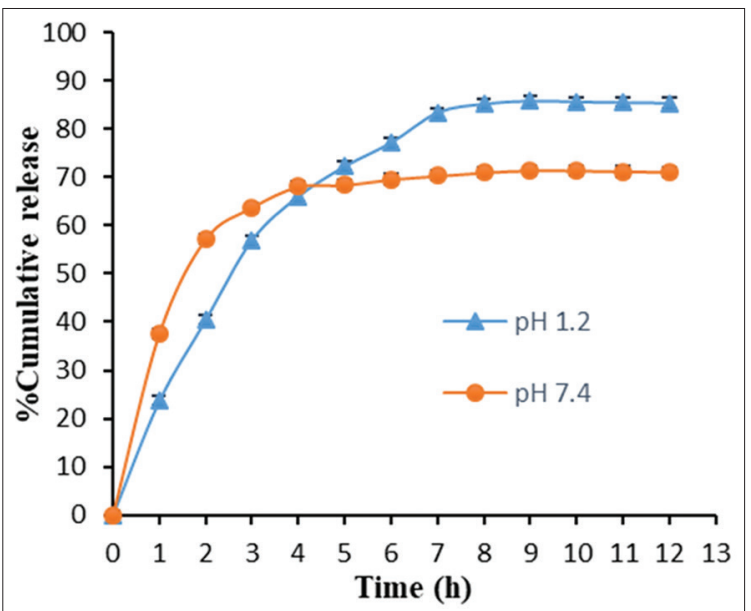

Fig. 5: Release pattern of $\mathrm{CLI}_{2}$ in simulated gastric fluid (pH 1.2) and simulated intestinal fluid ( $\mathrm{pH}$ 7.4). Error bars represent the standard deviation $(n=4)$

simulated fluid into the pores of the clinoptilolites and dissolves the trapped metformin $\mathrm{HCl}$ molecules. The dissolved drug molecule then diffuses out of pores $[50,51]$.

The release of metformin $\mathrm{HCl}$ from clinoptilolites in the simulated gastric fluid is higher than that in the simulated intestinal fluid. This indicates that the positively charged protons $\left(\mathrm{H}^{+}\right)$in the solution force the drugs to diffuse out through cation exchange [52]. However, this condition seems to be difficult to happen in a simulated intestinal fluid, since the concentration of $\mathrm{H}^{+}$is decreased at higher $\mathrm{pH}$. The release kinetics data of metformin $\mathrm{HCl}$ from clinoptilolites were fitted into four kinetic models, namely zero-order, first-order, Higuchi, and KorsmeyerPeppas models. As seen in Table 2, the release kinetics data of metformin $\mathrm{HCl}$ from clinoptilolites were best fitted into Korsmeyer-Peppas model with $\mathrm{R}^{2}$ value of 0.9776 (with $\mathrm{n}=0.69$ ) in $\mathrm{pH} 1.2$ and of 0.9119 (with $\mathrm{n}=0.64)$ in $\mathrm{pH}$ 7.4. The $\mathrm{n}$ value of 0.69 and $0.64(0.45<\mathrm{n}<0.89)$ suggested the non-Fickian transport mechanism [53].

\section{CONCLUSION}

Encapsulation of metformin $\mathrm{HCl}$ in clinoptilolite has been successfully conducted using the wet impregnation method. The FTIR spectra confirmed the existence of metformin $\mathrm{HCl}$ by absorption peak shifts of clinoptilolite functional groups. The XRD results showed that there were no changes in clinoptilolite crystallinity when metformin $\mathrm{HCl}$ was encapsulated on clinoptilolites. BET surface area of clinoptilolites was found to decrease as the metformin $\mathrm{HCl}$ encapsulated. The highest amount of drugs encapsulated on clinoptilolites was occurring at pH 7.0 and initial concentration of $300 \mathrm{mg} / \mathrm{l}$. The cumulative release of metformin $\mathrm{HCl}$ from clinoptilolites in the simulated gastric fluid was higher than that in a simulated intestinal fluid, which indicated the strong influence of $\mathrm{pH}$ on the release properties of the drug. Surface modification is needed to increase the amount of metformin $\mathrm{HCl}$ encapsulated on clinoptilolite. The drug release kinetics of metformin $\mathrm{HCl}$ from clinoptilolite was best fitted into the Korsmeyer-Peppas model with $\mathrm{n}$ value of 0.69 (pH 1.2) and 0.64 (pH 7.4) suggested nonFickian transport mechanism.

\section{ACKNOWLEDGMENT}

Authors are thankful to the Research and Community Service Institution, University of Dhyana Pura for providing financial assistance through the Hibah Unggulan Perguruan Tinggi (Higher Education Excellent Grants) 2017.

\section{AUTHORS' CONTRIBUTIONS}

I Made Wisnu Adhi Putra, has provided research conception and method, conducted the experiment in the laboratory, and authored the manuscript. I Gusti Ayu Wita Kusumawati has conducted experiment in the laboratory and analyzed the obtained data.

\section{CONFLICTS OF INTEREST}

All authors have none to declare.

\section{REFERENCES}

1. Seino Y, Nanjo K, Tajima N, Kadowaki T, Kashiwagi A, Araki E, et al. Report of the committee on the classification and diagnostic criteria of diabetes mellitus. J Diabetes Invest 2010;1:212-28.

2. Mihardja L, Soetrisno U, Soegondo S. Prevalence and clinical profile of diabetes mellitus in productive aged urban Indonesians. J Diabetes Invest 2014;5:507-12.

3. Hostalek U, Gwilt G, Hildemann S. Therapeutic use of metformin in prediabetes and diabetes prevention. Drugs 2015;75:1071-94.

4. Deepika D, Satish SK, Lalit S. Current updates on anti-diabetic therapy. J Drug Deliv Ther 2013;3:121-6.

5. Reinehr T. Type 2 diabetes mellitus in children and adolescents. World J Diabetes 2013;4:270-81

6. Ito H, Ishida H, Takeuchi Y, Antoku S, Abe M, Mifune M, et al. Longterm effect of metformin on blood glucose control in non-obese patients with Type 2 diabetes mellitus. Nutr Metab (Lond) 2010;7:83-91.

7. Inzucchi SE, Lipska KJ, Mayo H, Bailey CJ, McGuire DK. Metformin in patients with Type 2 diabetes and kidney disease: A systematic review. J Am Med Assoc 2014:312:2668-75.

8. Graham GG, Punt J, Arora M, Day RO, Doogue MP, Duong JK, et al. Clinical pharmacokinetics of metformin. Clin Pharmacokinet 2011;50:81-98.

9. Nayak AK, Pal D, Santra K. Tamarind seed polysaccharide-gellan mucoadhesive beads for controlled release of metformin $\mathrm{HCl}$. Carbohydr Polym 2014;103:154-63.

10. de Jager J, Kooy A, Lehert P, Wulffelé MG, van der Kolk J, Bets D, et al. Long term treatment with metformin in patients with Type 2 diabetes and risk of Vitamin B-12 deficiency: Randomised placebo controlled trial. BMJ Br Med J 2010;340:1-7.

11. Dumitrescu R, Mehedintu C, Briceag I, Purcarea VL, Hudita D. Metformin-clinical pharmacology in PCOs. J Med Life 2015;8:187-92.

12. Mosab A. Approaches to achieve an oral controlled release drug delivery system using polymers: A recent review. Int J Pharm Pharm Sci 2015;7:16-21.

13. Snima KS, Jayakumar R, Unnikrishnan AG, Nair SV, Lakshmanan VK. O-carboxymethyl chitosan nanoparticles for metformin delivery to pancreatic cancer cells. Carbohydr Polym 2012;89:1003-7.

14. Jose P, Sundar K, Anjali CH, Ravindran A. Metformin-loaded BSA nanoparticles in cancer therapy: A new perspective for an old antidiabetic drug. Cell Biochem Biophys 2014;71:627-36.

15. Das S, Samanta A, De HS. Formulation, in-vitro release kinetics and stability interpretation of sustained release tablets of metformin hydrochloride. Int J Pharm Pharm Sci 2015;7:418-22.

16. Raj J, Uppuluri KB. Metformin loaded casein micelles for sustained delivery: Formulation, characterization and in-vitro evaluation. Biomed Pharmacol J 2015;8:83-9.

17. Nayak AK, Pal D, Santra K. Swelling and drug release behavior of metformin $\mathrm{HCl}$-loadedtamarind seed polysaccharide-alginate beads. 
Int J Biol Macromolec 2016;82:1023-7.

18. Saini N, Sodhi RK, Bajaj L, Pandey RS, Jain UK, Katare OP, et al. Intravaginal administration of metformin hydrochloride loaded cationic niosomes amalgamated with thermosensitive gel for thetreatment of polycystic ovary syndrome: In vitro and in vivo studies. Colloids Surf B Biointerfaces 2016;144:161-9.

19. Hirvonen J, Laaksonen T, Peltonen L, Santos H, Lehto VP, Heikkilä T, et al. Feasibility of silicon-based mesoporous materials for oral drug delivery applications. Dosis 2008;24:129-49.

20. Amorim R, Vilaça N, Martinho O, Reis RM, Sardo M, Rocha J. Zeolite structures loading with an anticancer compound as drug delivery systems. [J Phys Chem C 2012;116:25642-50.

21. Pavelić K, Hadžija M, Bedrica L, Pavelić J, Đikić I, Katić M, et al. Natural zeolite clinoptilolite: New adjuvant in anticancer therapy. J Mol Med 2000;78:708-20.

22. Topashka-Ancheva M, Beltcheva M, Metcheva R, Rojas JA, RodriguezDe la Fuente AO, Gerasimova T, et al. Modified natural clinoptilolite detoxifies small mammal's organism loaded with lead II: Genetic, cell, and physiological effects. Biol Trace Elem Res 2012;147:206-16.

23. Farías T, de Ménorval LC, Zajac J, Rivera A. Benzalkonium chloride and sulfamethoxazole adsorption onto natural clinoptilolite: Effect of time, ionic strength, $\mathrm{pH}$ and temperature. J Colloid Interface Sci 2011;363:465-75.

24. Francisco M, Mlinar AN, Yoo B, Bell AT, Prausnitz JM. Recovery of glucose from an aqueous ionic liquid by adsorption onto a zeolite-based solid. Chem Eng J 2011;172:184-90.

25. Rimoli MG, Rabaioli MR, Melisi D, Curcio A, Mondello S, Mirabelli R, et al. Synthetic zeolites as a new tool for drug delivery. J Biomed Mater Res A 2008;87:156-64

26. Jevtić S, Grujić S, Hrenović J, Rajić N. Surfactant-modified clinoptilolite as a salicylate carrier, salicylate kinetic release and its antibacterial activity. Microporous Mesoporous Mater 2012;159:30-5.

27. Anghel I, Grumezescu AM, Anghel AG, Chireac I, Marutescu L, Mihaiescu DE, et al. Antibiotic potentiator effect of the natural and synthetic zeolites with well defined nanopores with possible ent clinical applications. Farmacia 2012;60:688-95.

28. Gennaro B, Catalanotti L, Cappelletti P, Langella A. Surface modified natural zeolite as a carrier for sustained diclofenac release: A preliminary feasibility study. Colloids Surf B Biointerfaces 2015;30:101-9.

29. Guan H, Bestland E, Zhu C, Zhu H, Albertsdottira D, Hutsona J, et al. Variation in performance of surfactant loading and resulting nitrate removal among four selected natural zeolites. J Hazard Mater 2010;183:616-21.

30. Nallaguntla L, Muzib Y, Aukunuru J, Balekari U. Novel nanoparticles for the oral delivery of low molecular weight heparin: In vitro and in vivo assessment. Asian J Pharm Clin Res 2017;10:254-61.

31. Heister E, Neves V, Lamprecht C, Silva SR, Coley HM, McFadden J. Drug loading, dispersion stability, and therapeutic efficacy in targeted drug delivery with carbon nanotubes. Carbon 2012;50:622-32.

32. Eren ZS, Tunçer S, Gezer G, Yildirim LT, Banerjee S, Yilmaz A. Improved solubility of celecoxib by inclusion in SBA-15 mesoporous silica, drug loading in different solvents and release. Microporous Mesoporous Mater 2016;235:211-23.

33. Vaingankar P, Amin P. Continuous melt granulation to develop high drug loaded sustained release tablet of metformin $\mathrm{HCl}$. Asian J Pharm Sci 2017; 12:37-50

34. Ghasemi F, Ghasemi K, Rezvani AR, Shokrollahi A, Refahi M, GarcíaGranda S, et al. A novel salt of antidiabetic drug metformin resulting from a proton transfer reaction: Synthesis, characterization, crystal structure and solution studies. J Mol Struct 2017;1131:30-5.

35. Hou D, Gui R, Hu S, Huang Y, Feng Z, Ping Q. Preparation and characterization of novel drug-inserted-montmorillonite chitosan carriers for ocular drug delivery. Adv Nanopart 2015;4:70-84

36. Youssef HF, Hegazy WH, Abo-almaged HH. Preparation and characterization of micronized zeolite Na-A: Cytotoxic activity of silver exchanged form. J Porous Mater 2015;22:1033-41.

37. Favvas EP, Tsanaktsidis CG, Sapalidis AA, Tzilantonis GT, Papageorgiou SK, Ch MA. Clinoptilolite, a natural zeolite material: Structural characterization and performance evaluation on its dehydration properties of hydrocarbon-based fuels. Microporous Mesoporous Mater 2016;225:385-91.

38. Khataee A, Bozorg S, Khorram S, Fathinia M, Hanifehpour Y, Joo SW. Conversion of natural clinoptilolite microparticles to nanorods by glow discharge plasma: A novel fe-impregnated nanocatalyst for the heterogeneous fenton process. Ind Eng Chem Res 2013;52:18225-33.

39. Martinho O, Vilaça N, Castro PJ, Amorim R, Fonseca AM, Baltazar F, et al. In vitro and in vivo studies of temozolomide loading in zeolite structures as drug delivery systems for glioblastoma. RSC Adv 2015;5:28219-27.

40. Jamalzadeh Z, Haghighi M, Asgari N. Synthesis and physicochemical characterizations of nanostructured $\mathrm{Pd} /$ carbon-clinoptilolite- $\mathrm{CeO}_{2}$ catalyst for abatement of xylene from waste gas streams at low temperature. J Ind Eng Chem 2013;20:2735-44.

41. Król M, Mozgawa W, Morawska J, Pichór W. Spectroscopic investigation of hydrothermally synthesized zeolites from expanded perlite. Microporous Mesoporous Mater 2014;196:216-22.

42. Farías T, Ruiz-Salvador AR, Velazco L, de Ménorval LC, Rivera A. Preparation of natural zeolitic supports for potential biomedical applications. Mater Chem Phys 2009;118:322-8.

43. Nezamzadeh-Ejhieh A, Tavakoli-Ghinani S. Effect of a nano-sized natural clinoptilolite modified by the hexadecyltrimethyl ammonium surfactant on cephalexin drug delivery. C R Chim 2013;17:49-61.

44. Narin G, Albayrak CB, Ülkü S. Preparation and characterization of antibacterial cobalt exchanged natural zeolite/poly(vinyl alcohol) hydrogels. J Sol Gel Sci Technol 2014;69:214-30.

45. Tomečková V, Reháková M, Mojžišová G, Magura J, Wadsten T, Zelenáková K. Modified natural clinoptilolite with quercetin and quercetin dihydrate and the study of their anticancer activity. Microporous Mesoporous Mater 2012;147:59-67.

46. Dziedzicka A, Sulikowski B, Ruggiero-Mikołajczyk M. Catalytic and physicochemical properties of modified natural clinoptilolite. Catal Today 2015;259:50-8

47. Łukarska M, Jankowska A, Gapiński J, Valable S, Anfray C, Ménard, B, et al. Synthesis and encapsulation of fluorescein in zeolite Y. Microporous Mesoporous Mater 2016;236:79-84.

48. Putra IM, Mustika IG. Potensi zat aktif antikanker solasodin terenkapsulasi pada zeolit klinoptilolit sebagai sistem penghantar obat (drug delivery system). Cakra Kimia 2016;4:103-12.

49. Rabiei M, Sabahi H, Rezayan AH. Gallic acid-loaded montmorillonite nanostructure as a new controlled release system. Appl Clay Sci 2016;119:236-42.

50. Putra IM, Sitanggang KW, Suarya P, Simpen IN, Cipta I. In vitro controlled drug release of antidiabetic metformin $\mathrm{HCl}$ from citric acid activated natural montmorillonite. Asian J Chem 2018;30:63-5.

51. Ceci-Ginistrelli E, Pontremoli C, Pugliese D, Barbero N, Boetti NG, Barolo C. Drug release kinetics from biodegradable UV-transparent hollow calcium-phosphate glass fibers. Mater Lett 2017;191:116-8.

52. Joshi GV, Patel HA, Kevadiya BD, Bajaj HC. Montmorillonite intercalated with vitamin B as drug carrier. Appl Clay Sci 2009:45:248-53.

53. Kharwade RS, More SM, Mahajan UN. Formulation and evaluation of gastroretentive floating tablet using Hibiscus rosa-sinensis mucilage. Asian J Pharm Clin Res 2017;10:444-8. 